\title{
College Students' Sexual Orientation, Gender Identity, and Participation in Study Abroad
}

\author{
Kelly M. Bryant \\ Krista M. Soria \\ University of Minnesota-Twin Cities
}

College students in the U.S. are increasingly participating in study abroad opportunities; for example, from the 2010-2011 academic year, 273,996 U.S. students studied abroad, an increase of 1.3\% from the previous year (Institute of International Education, 2012). Participation in study abroad has more than tripled over the past two decades (Institute of International Education, 2012) and, over the past 15 years, there has been growth in the number of study abroad locations available to college students (Landau \& Moore, 2001). Several authors have demonstrated the significant benefits college students glean from studying abroad; for example, students who study abroad can add the experience to their résumé, which allows them to become more competitive in an increasingly global job market (LaFranchi, 2003). No matter where students study abroad or how long they study abroad, students benefit from increased knowledge of their own cultural values and biases as well as a desire to further their education after college (McMillan \& Opem, 2002).

Students who study abroad also gain skills needed to become leaders, increase their personal growth (Dolby, 2007; McMillan \& Opem, 2002; Opper, Teichler, \& Carlson, 1990), become more independent (Hadis, 2005; Opper et al., 1990), and gain self-efficacy when achieving academic success, encountering difficult situations, and increasing their self-confidence (Cubillos \& Ilvento, 2013; Opper et al., 1990). Students who study abroad are more culturally sensitive and more likely to engage in work alongside people who are different from themselves (Dolby, 2007; Norris \& Gillespie, 2009; Opper et al., 1990; Stebleton, Soria, \& Cherney, 2013). U.S. students studying abroad also develop a better understanding of their role in the world as American citizens as well as the geopolitical realities in other countries (Dolby, 2004, 2007). Students who study abroad gain a sense of global-mindedness (Soria \& Troisi, 2013; Twombly, Salisbury, Tumanut, \& Klute, 2012), which involves "a concern for issues and processes that affect the world, as well as awareness that local issues are connected to global ones" (Hadis, 2005, p. 61). When students adapt to environments different from their own, they gain personal growth and reassess their values (Myers, Hill, \& Harwood, 2005). After students return from their study abroad experience, many are also more interested in becoming involved in student activities on campus (LaFranchi, 2003).

Yet, despite the many benefits to be gained from studying abroad, several authors have noted disparities in study abroad participation between students of different genders (Salisbury, Paulsen, \& Pascarella, 2011), income levels (Otero, 2008), races and ethnicities (Brux \& Fry, 2010; Burkart, Hexter, \& Thompson, 2001; Carew, 1993; Jackson, 2005; Salisbury et al., 2011), and abilities (Hameister, Matthews, Hosley, \& Groff, 1999; Johnson, 2000; Scheib \& Mitchell, 2008; Shames \& Alden, 2005; Soneson \& Cordano, 2009; Soneson \& Fisher, 2011; Twill \& Guzzo, 2012); for example, researchers have discovered that female college students are far more likely than male students to seek international opportunities (Talburt \& Stewart, 1999; Twombly, 1995; Twombly et al., 2012). Schmidt (2009) suggested that the gender gap arises because men are more 
likely to be influenced by peer interactions, whereas women are more likely to be influenced by authority figures, peer interactions, decisions on a major, and whether the study abroad courses will fit into their academic programs.

Low-income students also study abroad less frequently than their peers from higher income families. Burkart et al. (2001) and Twombly et al. (2012) suggested that low-income students may opt out of study abroad experiences because they do not think they can afford an international experience. Similar challenges face students of color in higher education; for example, students of color make decisions about educational opportunities differently than their peers, and financial aspects are one influence students of color consider before and during college (Brux \& Fry, 2010; Jackson, 2005; Salisbury et al., 2011). The affordability of study abroad matters: Salisbury et al. (2011) discovered that Hispanic students who received a federal grant were significantly more likely to study abroad than students who did not receive a grant. This example illustrates the importance of finances with study abroad decisions to students of color compared to their peers (Brux \& Fry, 2009; Jackson, 2005). Additionally, preconceived stereotypes can affect underrepresented students' decision to partake in international opportunities (Brux \& Fry, 2010; Carew, 1993; Jackson, 2005; Salisbury et al., 2011). Other barriers for students of color include lack of awareness of study abroad opportunities and lack of encouragement from faculty and family (Brux \& Fry, 2010; Jackson, 2005).

Students with disabilities also face barriers when studying abroad, including a lack of information, resources, and awareness that study abroad opportunities apply to them (Johnson, 2000; Scheib \& Mitchell, 2008; Soneson \& Cordano, 2009; Twill \& Guzzo, 2012). The ability to request necessary accommodations is another large barrier, as it can be difficult to request accommodations and students are often afraid to request accommodations because they think they will not have access to the same resources in the U.S. (Scheib \& Mitchell, 2008; Twill \& Guzzo, 2012). Students with disabilities are also often afraid of how people from other countries will view their disability (Johnson, 2000) and often lack encouragement to study abroad because of their disabilities (Hameister et al., 1999; Scheib \& Mitchell, 2008).

Despite what we know about the identity-related factors prohibiting some student populations from studying abroad, there is a lack of research related to whether similar factors affect the study abroad participation rates of students from various gender and sexual orientation identity groups, that is, lesbian, gay, bisexual, transgender, questioning, or queer (LGBTQQ) students. This lack of research is concerning because LGBTQQ students face challenges many of their peers do not normally have to confront. These challenges may extend to international venues and influence LGBTQQ students' decisions to study abroad; for example, LGBTQQ students may encounter discrimination when coming out to friends, families, or others, and society can exacerbate these difficult conditions because LGBTQQ individuals are "second-class citizens in their own culture" (Dunlap, 2003, para. 17). Around the world, many individuals in LGBTQQ communities face oppression and exercise caution when discussing their sexual or gender identity (Shea, 2001). In higher education, some LGBTQQ students face chilly climates due to marginalization within the campus community (Lipka, 2011). Because of this marginalization, many LGBTQQ youth lack social support, experience a sense of isolation, and have a considerably higher rate of attempted suicide than heterosexual peers (Suicide Prevention Resource Center, 2008).

In addition to safety concerns at home, LGBTQQ students face safety, discrimination, and prejudicial concerns abroad as they experience different cultural norms about sexual orientation and gender identity; for 
example, Gimelstein (2012) detailed the experiences of a lesbian student who studied abroad in Russia and encountered discrimination from her professor based on her sexual orientation. The U.S. Department of State (2013) delivered a statement on issues and conditions facing LGBTQQ students studying abroad in some countries where anti-gay legislation and anti-gay violence can lead to deportation, verbal harassment, stalking, intimidation, violence, and many worse consequences for LGBTQQ students. When LGBTQQ students study abroad, the legal system in their study abroad location may not offer them protection based on their sexual orientation. These factors may play into LGBTQQ students' decisions to study abroad.

Although there are many campus resources describing how LGBTQQ students can prepare for a study abroad trip (NAFSA, 2011), little research exists about whether LGBTQQ students are significantly more likely than their peers to opt out of study abroad due to some of the aforementioned concerns. Therefore, the purpose of this study is to fill this gap in research by examining whether there are associations between college students' sexual orientation and gender identity and their participation in study abroad. Specifically, we aim to examine whether LGBTQQ students are significantly more or less likely to participate in four types of study abroad controlling for other demographic factors and college experiences. The study abroad areas under focus in this study include 1) study abroad with students' home campus, 2) study abroad through another university, 3) travel abroad for service learning or volunteerism, and 4) travel abroad for cross-cultural experiences. Given some of the challenges LGTBQQ students face with regard to discrimination at home and abroad, we hypothesize that these students are much less likely than their peers to participate in these four study abroad areas.

\section{Study Abroad and LGBTQQ Students' Development}

Over the last three decades, several theories have advanced understanding of LGBTQQ students' identity development (Cass, 1979; D’Augelli, 1994; Fassinger, 1998; Troiden, 1989). For LGBTQQ students, identity development is much more complicated than for their heterosexual peers because many LGBTQQ students face discrimination in their communities and encounter not only heteronormativity, but also strong heterosexual bias, in the U.S. culture (Dunlap, 2003). In this paper, we draw upon D'Augelli's (1994) model of lesbian, gay, and bisexual development as a conceptual frame that may help us to understand the interplay between LGBTQQ students' developmental pathways and their decisions to study abroad. D'Augelli identified six interactive and non-linear processes that can explain individuals' lesbian, gay, or bisexual identity development. In the first process, described as exiting heterosexual identity and developing a personal lesbian/gay/bisexual identity status, individuals recognize that their feelings and attractions are not heterosexual and challenge internalized myths about what it means to be lesbian/gay/bisexual (D'Augelli, 1994). Individuals may progress (or regress) toward developing a lesbian/gay/bisexual social identity, identity as a lesbian/gay/bisexual son or daughter, develop intimate lesbian/gay/bisexual relationships, and enter lesbian/gay/bisexual communities (D’Augelli, 1994). We hypothesize that students within different identity development processes may make different choices regarding their decisions to study abroad; for example, a student who has developed a lesbian/gay/bisexual social identity, formed intimate relationships, and joined a lesbian/gay/bisexual community may be more affirmed in their sexual orientation identity and may make a more confident decision to study abroad. One who is still questioning sexual orientation identity and exiting heterosexual identity may not choose to study abroad for fear that his or her identity may not be accepted in a different culture. LGBTQQ students in the earlier stages of development who study abroad may use their 
experience as a time to experiment with coming out, although they may be forced to return to a life with limited or no support upon re-entry (Dunlap, 2003); however, those students who are in the later stages of the coming out process and have already incorporated a higher degree of acceptance may have a hard time coming out again in a different culture (Dunlap, 2003).

We also hypothesize that participating in study abroad may help students with the two processes of developing a personal lesbian/gay/bisexual identity status and developing a lesbian/gay/bisexual social identity (D’Augelli, 1994). When individuals develop a personal lesbian/gay/bisexual identity status, they determine what it means to be gay, lesbian, or bisexual in one's life and developing a lesbian/gay/bisexual social identity entails creating a support network of people who know and accept their sexual orientation (Evans, Forney, Guido, Patton, \& Renn, 2010). Study abroad may serve as a catalyst for students' sexual identity development; for example, students who study abroad in a welcoming culture and location for LGBTQQ individuals may experience more acceptance and may become more affirmed in their LGBTQQ identity (D’Aguelli, 1994).

The environmental contexts of study abroad are too important to overlook with regard to their contributions to students' identity development (Stevens, 2004). Students who study abroad must "assess the environmental norms and then figure out how they fit or do not fit into their new environments" (Stevens, 2004 , p. 186). Study abroad can offer an opportunity to be in a new environment that will allow students to be more open about their identity exploration, depending on the country or cultural acceptance. Many times, cultural taboos and familial expectations can be very burdensome to individuals (Stevens, 2004) and a new environment allows them to have time away from these afflictions to explore their identity. While D'Augelli's (1994) model is useful in unpacking all of the developmentally-based decisions students may make when choosing to study abroad, in this particular study, our primary concern is to ascertain whether LGBTQQ students are more or less likely to study abroad than their heterosexual or cisgender peers.

\section{Methods}

\section{Instrument}

The Student Experience in the Research University (SERU) survey is based at the Center for Studies of Higher Education (CSHE) at the University of California, Berkeley. The SERU survey sampling plan is a census scan of the undergraduate experience, and undergraduates enrolled in spring 2011 were included in this web-based questionnaire, with the majority of communication occurring by electronic mail. In the SERU survey, students answered a set of core questions and were randomly assigned one of four modules containing items focused specifically on a research theme. The core questions focus on time use, evaluation of a student's major, campus climate and satisfaction, serving to highlight four thematic research areas: academic engagement, community and civic engagement, global knowledge and skills, and student life and development. The items used in this analysis were located in a module assessing students' global and international experiences. 


\section{Participants}

The SERU survey was administered to 213,160 undergraduate students across eight large, public universities classified by the Carnegie Foundation as having very high research activity. The average institutional level completion response rate (as measured by the number of students who answered the majority of items on the first page of the survey) was $37.92 \%(n=80,837)$. From this larger sample, we used a smaller subsample of $30 \%$ of students who were randomly assigned to complete a module related to their academic engagement in global contexts. Among these students, we used only those who responded to the specific questions of the module that were important in the present study. Because the questions were located at the end of the module, which was located at the end of the lengthy survey, the sample comprised $24.39 \%$ of the original respondents $(n=19,715)$. Table 1 demonstrates the respondents' demographic characteristics.

\section{Measures}

Independent measures. Students identified their sexual orientation by selecting one of the following choices: bisexual, gay/lesbian, heterosexual, questioning, self-identified queer, decline to state, or other. In a separate question, students identified their gender as man/male, woman/female, transgender, genderqueer, decline to state, or other. We dummy-coded the primary sexual orientation variables of interest, with students who selected heterosexual, other, or decline to state options as the common referent. We also dummy-coded the gender items of interest, with students who selected male, female, decline to state, and other as common referent groups. Even though our SERU sample size was considerable, students who identified as bisexual, gay or lesbian, questioning, queer, transgender, or genderqueer in total comprised less than $6 \%$ of our overall sample.

We also selected several control variables previously demonstrated to influence students' decisions to study abroad (Brux \& Fry, 2010; Jackson, 2005; Salisbury, Paulsen, \& Pascarella, 2011; Talburt \& Stewart, 1999; Twombly, 1995; Twombly et al., 2012). We used several demographic control variables in our models, including race and ethnicity (dummy-coded; for example, Hispanic students $=1$, students from all other race/ethnicity categories $=0$ ). As a measure of socioeconomic status, we relied upon students' self-reported social class. In the survey, students were asked to identify their social class through the question, "Which of the following best describes your social class when you were growing up?" Students could select one of the following categories: wealthy, upper-middle or professional-middle, middle-class, working-class, and lowincome or poor. Low-income and working-class categories were dummy-coded with all other social class groups as referents. Prior research has suggested that students are relatively accurate in identifying their social class categories when comparing social class with objective financial and parental education indicators (Soria \& Barratt, 2012).

Because we used all academic levels of undergraduates in this analysis, we included the credits students had earned as a control variable. We derived students' cumulative grade point averages from fall semester, as the survey was administered at all institutions in the middle of the spring semester. Finally, we also included students' academic majors, which we reviewed and categorized in a few primary areas (e.g., arts, humanities, and languages; science, technology, math, and engineering, etc.). Institutions provided all of the credit, grade point average, and academic major variables. 
Dependent measures. Within the randomly assigned survey module, students were asked about their participation in study abroad or travel experiences. The item began by asking, "have you completed or are you now participating in the following activities?" The options included any study abroad program, including summer study abroad; study abroad program affiliated with another college or university; traveled abroad for a service learning, volunteer, or work experience; or traveled abroad for cross-cultural experience or informal education. Some of the study/travel abroad experiences may not have been viewed by students as mutually exclusive from one another and students may have selected more than one category to describe a single study abroad experience (e.g., students may have traveled through a university study abroad program in which service learning was also a component). In our sample, $10.63 \%$ of students studied abroad with their home campus, $5.86 \%$ studied abroad with another campus, $13.29 \%$ traveled abroad for service learning or work experience, and $17.27 \%$ traveled abroad for a cross-cultural or informal educational experience.

\begin{tabular}{|c|c|c|}
\hline Categorical Variables & $n$ & $\%$ \\
\hline Bisexual & 409 & 2.07 \\
\hline Gay or Lesbian & 429 & 2.18 \\
\hline Questioning & 172 & 0.87 \\
\hline Self-identified Queer & 70 & 0.36 \\
\hline Transgender & 22 & 0.11 \\
\hline Genderqueer & 47 & 0.24 \\
\hline Female & 11379 & 57.72 \\
\hline American Indian or Native American & 78 & 0.40 \\
\hline Black & 1030 & 5.22 \\
\hline Hispanic & 2273 & 11.53 \\
\hline Asian & 3104 & 15.74 \\
\hline Other or Unknown Race & 887 & 4.50 \\
\hline International & 831 & 4.22 \\
\hline Low-Income & 1112 & 5.64 \\
\hline Working-Class & 3678 & 18.66 \\
\hline Study Abroad with Home Campus & 2096 & 10.63 \\
\hline Study Abroad with Another Campus & 1155 & 5.86 \\
\hline Travel Abroad for Service Learning, Volunteer, or Work Experience & 2621 & 13.29 \\
\hline Travel Abroad for Cross-Cultural or Informal Educational Experience & 3402 & 17.26 \\
\hline STEM Major & 5910 & 29.98 \\
\hline Arts and Humanities Major & 3171 & 16.08 \\
\hline Social Sciences Major & 2237 & 11.35 \\
\hline Business Major & 2639 & 13.39 \\
\hline Education Major & 288 & 1.46 \\
\hline Health and Human Services Major & 1957 & 9.93 \\
\hline Continuous Variables & Mean & $\begin{array}{l}\text { Standard } \\
\text { Deviation }\end{array}$ \\
\hline Grade Point Average & 3.172 & .776 \\
\hline Credits & 61.604 & 38.810 \\
\hline
\end{tabular}




\section{Procedures}

To address our research question, we employed logistic regression analyses predicting students' involvement in the four study abroad and travel experiences. We examined multicollinearity assumptions for the logistic regressions analyses. We ran collinearity diagnostics for logistic regression using ordinary least squares (OLS) regression, as SPSS does not have an option to produce collinearity diagnostics for logistic regression analysis (Field, 2009). Multicollinearity assumptions were not violated (tolerance statistics were between .42 and .99 and variance inflation factors ranged from 1.01 to 2.36). Logistic regression makes no assumptions about the distribution of the independent variables, including assumptions of normality (Field, 2009). Standardized residual statistics were examined and there was no evidence of influential cases having an effect on the models (there were no unusually high values of Cook's distance, DFBeta, and leverage statistics) (Field, 2009). In assessing our model fits, we examined Hosmer \& Lemeshow's (2000) test statistics, which were non-significant and suggested adequate model fit $(p>.05)$.

Whereas beta coefficients, standard errors, and significance levels are commonly used to describe the results of ordinary least squares regression, odds ratios, which are calculated by exponentiating the beta coefficient $\left(\mathrm{e}^{\mathrm{b}}\right)$, are used in logistic regression to explain how a change in an independent variable influences the dependent variable when other variables are held constant (Cragg, 2009; Hosmer \& Lemeshow, 2000). In the context of the present study, the odds ratio value indicates the odds of participating in study or travel abroad for every one-unit increase in a continuous independent variable when other variables are held constant. For the dummy-coded variables, the odds ratio indicates the odds of studying or traveling abroad for the target variable as compared to the reference variable.

\section{Results}

Table 2 presents the parameter estimates, standard errors, and odds ratios statistics from our first logistic regression analyses predicting students' participation in a study abroad program affiliated with their home universities. A test of the full model against a constant only model was statistically significant, indicating that the predictors are reliably distinguished between students who studied abroad and those who did not $\left(\chi^{2}\right.$ $=1175.03, p<.001, d f=23)$. The odds ratios suggest that bisexual and gay or lesbian students were significantly more likely to study abroad compared to their peers (Table 2). Specifically, the model suggests that bisexual students were 1.388 times more likely to study abroad and gay or lesbian students were 1.475 times more likely to study abroad, on average, than their peers. In this model, questioning, self-identified queer, transgender, and genderqueer students were not significantly more or less likely to study abroad compared with their peers.

The second logistic regression analysis predicted students' participation in a study abroad program affiliated with another college or university. A test of the full model against a constant only model was statistically significant, indicating that the predictors are reliably distinguished between students who studied abroad and those who did not $\left(\chi^{2}=407.67, p<.001, d f=23\right)$. The odds ratio suggests that bisexual and gay or lesbian students were significantly more likely to participate in a study abroad program affiliated with another college or university compared to their peers (Table 2). Specifically, the model suggests that bisexual students were 1.514 times more likely to study abroad and gay or lesbian students were 1.496 times more likely to study abroad, on average, than their peers. In this model, questioning, self-identified queer, 
transgender, and genderqueer students were not significantly more or less likely to study abroad with another college or university program compared with their peers.

The third logistic regression analysis predicted students' travel abroad for service learning, volunteer, or work experience. A test of the full model against a constant only model was statistically significant, indicating that the predictors are reliably distinguished between students who traveled abroad and those who did not $\left(\chi^{2}\right.$ $=374.15, p<.001, d f=23)$. The odds ratio suggests that questioning, self-identified queer, and transgender students were significantly more likely to travel abroad for service learning, volunteer, or work experience compared to their peers (Table 2). Specifically, the model suggests that questioning students were 1.471 times more likely to travel abroad, self-identified queer students were 2.136 times more likely to travel abroad, and transgender students were 2.840 times more likely to travel abroad, on average, than their peers. In this model, bisexual, gay or lesbian, and genderqueer students were not significantly more or less likely to travel abroad than their peers.

The fourth logistic regression analysis predicted students' travel abroad for cross-cultural or informal educational experiences. A test of the full model against a constant only model was statistically significant, indicating that the predictors are reliably distinguished between students who traveled abroad and those who $\operatorname{did}$ not $\left(\chi^{2}=572.37, p<.001, d f=23\right)$. The odds ratio suggests that bisexual, questioning, and self-identified queer students were significantly more likely to travel abroad for cross-cultural or informal educational experiences compared to their peers (Table 2). Specifically, the model suggests that bisexual students were 1.278 times more likely to travel abroad, questioning students were 1.418 times more likely to travel abroad, and self-identified queer students were 1.864 times more likely to travel abroad, on average, than their peers. In this model, gay or lesbian, transgender, and genderqueer students were not significantly more or less likely to travel abroad than their peers.

A few predictors were significant across all logistic regression models; for examples, females were significantly more likely than males to study or travel abroad in all areas. Asian students were significantly less likely than their peers to study or travel abroad in all areas except for traveling abroad for service learning, volunteer, or work experience. International students were significantly more likely to travel or study abroad than their peers in all areas save for study abroad through their home university. Working-class students were significantly less likely to study or travel abroad compared with their peers in all areas and low-income students were significantly less likely to travel abroad in both areas than their peers.

Additionally, students' cumulative grade point average and number of credits earned were positively associated with study or travel abroad in all areas. Students in arts and humanities majors and business majors were more likely to study or travel abroad in all areas compared to their peers. Students in social sciences majors were more likely to study or travel abroad in all areas except for traveling abroad for service or work experience. Students in health and human services majors were more likely to travel abroad in both areas compared to their peers. Finally, students in STEM majors were more likely to travel abroad for crosscultural/informal educational experiences and study abroad with their home campus compared with their peers. Students in education majors were neither more nor less likely to study or travel abroad than their peers. 
Kelly M. Bryant \& Krista M. Soria

Table 2. Logistic Regression Analysis of Students' Participation in Study Abroad

\begin{tabular}{|c|c|c|c|c|c|c|}
\hline & \multicolumn{3}{|c|}{$\begin{array}{l}\text { Study Abroad Through Home } \\
\text { Campus }\end{array}$} & \multicolumn{3}{|c|}{$\begin{array}{l}\text { Study Abroad Through Another } \\
\text { University }\end{array}$} \\
\hline & B & SE & $e^{\beta}$ & $\mathrm{B}$ & SE & $e^{\beta}$ \\
\hline Constant & $-5.843^{* \star \star}$ & .200 & .003 & $-4.714^{* * *}$ & .213 & .009 \\
\hline Bisexual & $.328^{*}$ & .148 & 1.388 & $.415^{\star}$ & .181 & 1.514 \\
\hline Gay or Lesbian & $.389^{* *}$ & .148 & 1.475 & $.403^{*}$ & .184 & 1.496 \\
\hline Questioning & .046 & .255 & 1.047 & .063 & .319 & 1.065 \\
\hline Self-identified Queer & -.363 & .407 & .695 & -.170 & .499 & .843 \\
\hline Transgender & .881 & .643 & 2.414 & .816 & .761 & 2.262 \\
\hline Genderqueer & .523 & .429 & 1.686 & .866 & .477 & 2.378 \\
\hline Female & $.364^{* * *}$ & .053 & 1.439 & $.207^{* \star}$ & .067 & 1.230 \\
\hline American Indian or Native American & .030 & .386 & 1.030 & -.444 & .595 & .641 \\
\hline Black & -.081 & .120 & .922 & -.250 & .163 & .779 \\
\hline Hispanic & .068 & .078 & 1.071 & -.121 & .106 & .886 \\
\hline Asian & $-.247^{* *}$ & .073 & .781 & $-.268^{* *}$ & .096 & .765 \\
\hline Other or Unknown Race & .069 & .114 & 1.072 & $-.373^{*}$ & .172 & .689 \\
\hline International & -.230 & .130 & .795 & $.456^{\star * *}$ & .130 & 1.578 \\
\hline Low-Income & .042 & .111 & 1.043 & -.090 & .145 & .914 \\
\hline Working-Class & $-.180^{\star *}$ & .068 & .835 & $-.394^{* * *}$ & .093 & .674 \\
\hline Grade Point Average & $.676^{* * *}$ & .052 & 1.967 & $.281^{* * *}$ & .056 & 1.325 \\
\hline Credits & $.013^{* * *}$ & .001 & 1.013 & $.009^{* * *}$ & .001 & 1.009 \\
\hline STEM Major & $.207^{*}$ & .097 & 1.230 & .165 & .121 & 1.179 \\
\hline Arts and Humanities Major & $.739^{\star \star *}$ & .098 & 2.094 & $.667^{* * *}$ & .123 & 1.949 \\
\hline Social Sciences Major & $.519^{* * *}$ & .105 & 1.681 & $.495^{* \star *}$ & .133 & 1.640 \\
\hline Business Major & $.655^{\star * *}$ & .102 & 1.925 & $.631^{* * *}$ & .127 & 1.879 \\
\hline Education Major & -.471 & .267 & .625 & .068 & .295 & 1.071 \\
\hline Health and Human Services Major & -.111 & .122 & .895 & .057 & .151 & 1.059 \\
\hline$\%$ Correctly Predicted & 89.4 & & & 94.1 & & \\
\hline-2 log likelihood & 12181.519 & & & 8387.420 & & \\
\hline Pseudo $R^{2}$ (Cox \& Snell, 1989) & .058 & & & .020 & & \\
\hline Pseudo $R^{2}$ (Nagelkerke, 1991) & .118 & & & .057 & & \\
\hline
\end{tabular}


Table 2. (continued) Logistic Regression Analysis of Students' Participation in Study Abroad

\begin{tabular}{|c|c|c|c|c|c|c|}
\hline & \multicolumn{3}{|c|}{$\begin{array}{l}\text { Traveled Abroad for Service } \\
\text { Learning, Volunteer, or Work } \\
\text { Experience }\end{array}$} & \multicolumn{3}{|c|}{$\begin{array}{l}\text { Traveled Abroad for Cross-Cultural } \\
\text { Experience or Informal Education }\end{array}$} \\
\hline & $\mathrm{B}$ & SE & $e^{\beta}$ & $\mathrm{B}$ & SE & $e^{\beta}$ \\
\hline Constant & $-3.200^{\star \star *}$ & .131 & .041 & $-2.476^{\star \star \star}$ & .110 & .084 \\
\hline Bisexual & .032 & .147 & 1.032 & $.246^{*}$ & .124 & 1.278 \\
\hline Gay or Lesbian & -.007 & .150 & .993 & .093 & .132 & 1.098 \\
\hline Questioning & $.386^{*}$ & .203 & 1.471 & $.349^{\star}$ & .186 & 1.418 \\
\hline Self-identified Queer & $.759^{*}$ & .301 & 2.136 & $.623^{*}$ & .276 & 1.864 \\
\hline Transgender & $1.044^{*}$ & .501 & 2.840 & .508 & .531 & 1.661 \\
\hline Genderqueer & -.590 & .502 & .554 & .537 & .339 & 1.711 \\
\hline Female & $.108^{*}$ & .045 & 1.114 & $.195^{\star * \star}$ & .041 & 1.215 \\
\hline American Indian or Native American & .161 & .330 & 1.175 & -.132 & .319 & .876 \\
\hline Black & $-.241^{*}$ & .113 & .786 & $-.445^{\star * *}$ & .106 & .641 \\
\hline Hispanic & .022 & .072 & 1.022 & -.030 & .064 & .971 \\
\hline Asian & .046 & .061 & 1.048 & $-.186^{* *}$ & .058 & .831 \\
\hline Other or Unknown Race & $.231^{*}$ & .099 & 1.260 & .108 & .091 & 1.114 \\
\hline International & $.462^{* * *}$ & .095 & 1.587 & $.451^{* * *}$ & .086 & 1.570 \\
\hline Low-Income & $-.325^{\star \star}$ & .105 & .722 & $-.281^{* *}$ & .093 & .755 \\
\hline Working-Class & $-.393^{* * *}$ & .062 & .675 & $-.521^{* \star *}$ & .057 & .594 \\
\hline Grade Point Average & $.252^{* * *}$ & .035 & 1.287 & $.192^{* * *}$ & .030 & 1.211 \\
\hline Credits & $.006^{* \star *}$ & .001 & 1.006 & $.004^{\star * *}$ & .001 & 1.004 \\
\hline STEM Major & -.012 & .073 & .988 & $-.296^{\star * *}$ & .065 & .744 \\
\hline Arts and Humanities Major & $.260^{\star *}$ & .079 & 1.296 & $297^{\star * *}$ & .068 & 1.346 \\
\hline Social Sciences Major & .154 & .087 & 1.166 & $.155^{*}$ & .075 & 1.167 \\
\hline Business Major & $.201^{\star}$ & .082 & 1.222 & $.244^{* *}$ & .070 & 1.276 \\
\hline Education Major & .074 & .186 & 1.076 & -.296 & .178 & .744 \\
\hline Health and Human Services Major & $.269^{* *}$ & .088 & 1.309 & $-.169^{*}$ & .082 & .844 \\
\hline$\%$ Correctly Predicted & 86.7 & & & 82.7 & & \\
\hline-2 log likelihood & 15080.283 & & & 17562.300 & & \\
\hline Pseudo $R^{2}$ (Cox \& Snell, 1989) & .019 & & & .029 & & \\
\hline Pseudo $R^{2}$ (Nagelkerke, 1991) & .035 & & & .048 & & \\
\hline
\end{tabular}

\section{Discussion and Limitations}

There is much research written about the benefits of study abroad as well as the gaps in study abroad participation with particular student populations; however, there is little research completed on LGBTQQ students and study abroad. The results of our analyses suggest that bisexual, gay or lesbian, questioning, selfidentified queer, transgender, and genderqueer students were not significantly less likely to study or travel abroad in the four areas measured; instead, evidence from this sample suggests that these students may be more likely on average to participate in specific study or travel abroad experiences compared to their peers. Compared to their peers, bisexual and gay or lesbian students were significantly more likely to study abroad with their home campus or with another university; questioning, transgender, and self-identified queer students were more likely to travel abroad for service, volunteer, or work experiences; and bisexual, questioning, and self-identified queer students were more likely to travel abroad for cross-cultural or informal educational experiences. 
Given the importance of environmental contexts in shaping lesbian, gay, and bisexual students' identity development (Stevens, 2004), LGBTQQ students may choose to study abroad because it affords them opportunities to explore their sexual identity in a setting different from the one at home. Campuses that provide support and resources for LGBTQQ students who are interested in studying abroad may help students to feel more included within their college experience. College students not associated with the LGBTQQ community also become more accepting of LGBTQQ students through higher levels of interpersonal contact through co-curricular programs, such as study abroad, which can be used to foster greater acceptance of diversity among college students (Holland, Matthews, \& Schott, 2013). By integrating LGBTQQ students in study abroad programs, other students will then become more accepting of those different from themselves.

Our results also confirmed prior research suggesting that females were more likely to study abroad than males, low-income students also study abroad less frequently than their peers from higher income families, and students of color face similar challenges (Brux \& Fry, 2010; Bukart, Hexter, \& Thompson, 2001; Carew, 1993; Jackson, 2005; Otero, 2008; Salisbury et al., 2011; Schmidt, 2009; Talburt \& Stewart, 1999; Twombly, 1995; Twombly et al., 2012). While not the primary focus of this study, it is important not to neglect the persistent disparities in study abroad participation among these student populations. It is possible that these intersectional aspects of students' identities may also shape LGBTQQ students' decisions to study abroad; future researchers are encouraged to explore the ways in which these intersecting elements of students' identities shape their decisions to study abroad and the developmental outcomes associated with study abroad (Crenshaw, 1991).

There are several limitations to the present study. First, while the sample includes eight higher education institutions, the specific institutional context (large, public research universities) may limit the generalizable nature of the results. Additionally, we relied upon students' reports of their study abroad participation in four different contexts as opposed to institutional records which may have more accurately captured students' participation in different types of study abroad experiences (e.g., two-week short trip experiences, volunteer trips with student organizations, etc.). We acknowledge that there are many ways in which students can study abroad which were not fully captured by the present survey.

Furthermore, we used a limited theoretical framework to position our study. Future researchers are encouraged to employ theoretical frameworks specifically addressed to gender identity development of transgender and genderqueer students in their analyses. Finally, there are innumerable variables not included in our models which may have better predicted students' study abroad participation, including their intent or interest in studying abroad. Although these variables were not included in the survey, we encourage future researchers to incorporate them within future studies.

\section{Recommendations}

Amid these encouraging findings, we have recommendations for practitioners working to make the experiences of LGBTQQ students studying abroad better. Individuals in the LGBTQQ community should become aware of religious and traditional aspects of the culture they are living in as well as how to gain support (NAFSA, 1993). NAFSA (2000) advises students to gain country specific information on support groups available in the host country, familiarize themselves with the laws of the country, and talk with others 
in the LGBTQQ community who have studied abroad (Shea, 2001). When advising an LGBTQQ student who wants to study abroad, it is important to be knowledgeable and sensitive about certain situations in different countries, since many definitions of sexual identity and sexuality are culturally-based (NAFSA Rainbow SIG, 2011).

We also recommend that study abroad offices work with an office supporting LGBTQQ students to assist students in gaining the support necessary to study abroad (Rhodes, Biscarra, Loberg, \& Roller, 2012). LGBTQQ students should also be aware that even if the study abroad office at their home institution is inclusive of LGBTQQ perspectives, students, staff, and faculty in a host country may signify a less-welcoming climate for LGBTQQ identities (NAFSA Rainbow SIG, 2011). Those working in study abroad must then make sure LGBTQQ students are aware of these differences in culture to prepare students for potential culture shock with regards to acceptance of non-heterosexual, transgender, or genderqueer identities.

It is also important to continue to be supportive after LGBTQQ students study abroad, as re-entry may be just as difficult as preparing to study abroad (NAFSA Rainbow SIG, 2011). For example, a student may have established a new sense of freedom while abroad which may make it difficult to return to unsupportive friends or family (NAFSA Rainbow SIG, 2011). As such, it is essential support continues when the student returns to the home institution.

Because there is so little research written about LGBTQQ students and study abroad, we recommend that those working in study abroad and higher education research more about this particular student group. Those working in study abroad should also consider how an international experience may influence students' development. It is important to become aware of such models as D'Augelli's (1994) model of lesbian, gay, and bisexual development and how environmental contexts shape students' development. As such, it is essential for those working in study abroad and higher education to continue learning how study abroad may influence the LGBTQQ student community.

In response to better assisting LGBTQQ students study abroad, several college campuses have created resources to help LGBTQQ students have a successful and positive study abroad experience. These resources include written and online materials describing aspects LGBTQQ students should consider when preparing to travel abroad such as customs, attitudes, and laws of the host country; benefits of an international experience and LGBTQQ organizations around the world; and recommended books and articles dealing with study abroad and the LGBTQQ community (NAFSA SIG, 2000). Many of these resources have emerged within the last five years, although there are books published in the 1990s about LGBTQQ individuals living in other countries (Balderston \& Guy, 1997; Essig, 1999; Gevisser \& Cameron, 1995; Jackson, 1996; Lumsden, 1996; Merrick \& Ragan, 1996; Miller, 1992; Murray \& Roscoe, 1998; O’Carroll \& Collins, 1996; Parker, 1999; Seabrook \& Gopalan, 1999; Summerhawk, McMahill, \& McDonald, 1998; Thatchell, 1992). NAFSA: Association of International Educators has set up a resource for students in the LGBTQQ community who wish to study abroad called Rainbow Special Interest Group (SIG) ("NAFSA: Rainbow SIG," 2011). This group provides resources for students in the LGBTQQ community as well as international educators who wish to gain insight on how to help LGBTQQ U.S. and international students have a successful study abroad experience ("NAFSA: Rainbow SIG," 2011). 
We recommend those working in study abroad provide resources for students in the LGBTQQ community who are thinking about or planning to study abroad. These resources should include specific orientations to teach LGBTQQ students about the dangers they may run into and precautions they should take when studying abroad in a specific country. By collaborating with numerous offices on campus and providing resources for students, those working in higher education can ensure LGBTQQ students have a successful and fulfilling study abroad experience.

\section{Conclusion}

In conclusion, our study suggests that LGBTQQ students are more likely than their peers to study abroad in several areas. These encouraging results show that LGBTQQ students may glean many positive outcomes from studying abroad. Student affairs professionals and those working in higher education must encourage these students to obtain study abroad opportunities, as well as prepare them for the difficulties they may face. It is also crucial to be aware of where LGBTQQ students are in their development, and the experiences they may face abroad related to environmental factors. Considering these aspects, as well as the recommendations given above, will help to ensure LGBTQQ students have the necessary support for a rewarding study abroad experience.

\section{References}

Balderston, D., \& Guy, D. (1997). Sex and sexuality in Latin America. New York, NY: New York University.

Brux, J. M., \& Fry, B. (2010). Multicultural students in study abroad: Their interests, their issues, and their constraints. Journal of Studies in International Education, 14(5), 508-527. doi: $10.1177 / 1028315309342486$

Burkart, B., Hexter, H., \& Thompson, D. (2001). Why TRIO students need to study abroad. Retrieved from http://www.pellinstitute.org/downloads/trio_clearinghouse-opportunity_outlookC.pdf

Carew, J. G. (1993). Minority students abroad: An inspiring experience abroad. The Chronicle of Higher Education, Retrieved from http://chronicle.com.ezproxy.stthomas.edu/article /Minority-StudentsAbroad-an/71387/

Cass, V. C. (1979). Homosexual identity formation: A theoretical model. Journal of Homosexuality, 4, 219 235.

Cox, D. R., \& Snell, D. J. (1989). The analysis of binary data ( $2^{\text {nd }}$ Ed.). London, UK: Chapman \& Hall.

Cragg, K. M. (2009). Influencing the probability for graduation at four-year institutions: A multi-model analysis. Research in Higher Education, 50, 394-413.

Crenshaw, K. (1991). Mapping the margins: Intersectionality, identity politics, and violence against women of color. Stanford Law Review, 43(6), 1241-1299.

Cubillos, J. H., \& Ilvento, T. (2013). The impact of study abroad on students' self-efficacy perceptions. Foreign Language Annals, 45(4), 494-511. doi: 10.1111/flan.12002

D'Augelli, A. R. (1994). Identity development and sexual orientation: Toward a model of lesbian, gay, and bisexual development. In E. J. Trickett, R. J. Watts, D. Birman (Eds.), Human diversity: Perspectives on people in context (pp. 312-333). San Francisco, CA:Jossey-Bass.

Dolby, N. (2004). Encountering an American self: Study abroad and national identity. Comparative Education Review, 48(2), 150-173.

Dolby, N. (2007). Reflections on nation: American undergraduates and education abroad. Journal of Studies 
in International Education, 11(2), 141-156.

Dunlap, A. (2003). Coming out and coming back: Re-entry issues for GLBT college students who study abroad. NAFSA Rainbow SIG SIGnals Newsletter, 9(2). Retrieved from http://overseas.iu.edu/lesbigay/vol9_2/92re-entry.html

Essig, L. (1999). Queer in Russia: A story of sex, self, and the other. Durham, NC: Duke University Press.

Evans, N. J., Forney, D. S., Guido, F. M., Patton, L. D., \& Renn, K. A. (2010). Student development in college: Theory, research, and practice ( $2^{\text {nd }}$ ed.). San Francisco, CA: Jossey-Bass.

Fassinger, R. E. (1998). Lesbian, gay, and bisexual identity and student development theory. In R. L. Sanlo (Ed.), Working with lesbian, gay, bisexual, and transgender college students: A handbook for faculty and administrators. (pp. 13-32). Westport, CT: Greenwood.

Field, A. (2009). Discovering statistics using SPSS ( $3^{\text {rd }}$ ed.). Los Angeles, CA: Sage.

Gevisser, M., \& Cameron, E. (Eds.). (1995). Defiant desire: Gay and lesbian lives in South Africa. New York, NY: Routledge.

Gimelstein, S. (2012, April 8). LGBT students face challenges while studying abroad. The Daily Pennsylvanian. Retrieved from http://www.thedp.com/article/2012/04/lgbt_students_face_difficulties_while_studying_abroad

Hadis, B. F. (2005). Why are they better students when they come back? Determinants of academic focusing gains in the study abroad experience. Frontiers: The Interdisciplinary Journal of Study Abroad, 11, 57-70.

Hameister, B. G., Matthews, P. R., Hosley, N. S., \& Groff, M. C. (1999). College students with disabilities and study abroad: Implications for international education staff. Frontiers: The Interdisciplinary Journal of Study Abroad, 5(2), 81-100.

Holland, L., Matthews, T. L., \& Schott, M. R. (2013). “That's so gay!” exploring college students' attitudes toward the LGBT population. Journal of Homosexuality, 60(4), 575-595. doi: 10.1080/00918369.2013.760321

Hosmer, D. W., \& Lemeshow, S. (2000). Applied logistic regression (2 ${ }^{\text {nd }}$ ed.). New York, NY: Wiley-InterScience Publication.

Institute of International Education. (2012). Open doors report. Retrieved from http://www.iie.org/Researchand-Publications/Open-Doors

Jackson, M. J. (2005). Study abroad for students of color. IIE Networker: The International Education Magazine, Retrieved from

http://www.nxtbook.com/nxtbooks/naylor/IIEB0205/index.php?startid=16\#/16

Jackson, P.A. (1996). Dear uncle go: Male homosexuality in Thailand ( $2^{\text {nd }}$ ed.). San Francisco, CA: Bua Luang Publishing Company.

Johnson, D. (2000). Enhancing out-of-class opportunities for students with disabilities. New Directions for Students Services, 2000 (91), 41-53.

LaFranchi, H. (2003, August 19). Why more students are studying abroad: Reasons such as 'seeing the world' still prevail, but some students also want new views of the U.S. role. The Christian Science Monitor.

Landau, J., \& Moore, D. M. (2001). Towards reconciliation in the motherland: Race, class, nationality, gender, and the complexities of American student presence at the University of Ghana, Legon. Frontiers: The Interdisciplinary Journal of Study Abroad, 7(2), 25-59.

Lipka, S. (2011, March 6). For gay students, more room on campuses. The Chronicle of Higher Education.

Lumsden, I. (1996). Machos, maricones, and gays: Cuba and homosexuality. Philadelphia, PA: Temple University Press.

McMillan, A. R., \& Opem, G. (2002). Study Abroad: A Lifetime of Benefits. IES Abroad, Retrieved from http://www.iesabroad.org/study-abroad/news/study-abroad-lifetime-benefits

Merrick, J., \& Ragan, B. T. (1996). Homosexuality in Modern France (Studies in the History of Sexuality). New 
York, NY: Oxford University Press.

Miller, N. (1992). Out in the world: Gay and lesbian life from Buenos Aires to Bangkok. New York, NY: Random House.

Murray, S. O., \& Roscoe, W. (Eds.). (1998). Boy-wives and female-husbands: Studies of African homosexualities. New York, NY: St. Martin's Press.

Myers, D. N., Hill, M., \& Harwood, S. A. (2005). Cross-cultural learning and study abroad: Transforming pedagogical outcomes. Landscape Journal, 24(2), 172-184.

NAFSA: Association of International Educators. (1993). GLBT perspectives and study abroad orientations. Informal International Educational Task Force on GLBT Concerns, University of Minnesota. Retrieved from http://overseas.iu.edu/lesbigay/advise/orientations.html

NAFSA: Association of International Educators Rainbow Special Interest Group. (2011). Retrieved from http://overseas.iu.edu/lesbigay/

NAFSA Rainbow SIG. (2000). Student resources. Retrieved from http://overseas.iu.edu/lesbigay/student.htm

Nagelkerke, N. J. D. (1991). A note on a general definition of the coefficient of determination. Biometrika, 78, 691-692.

Norris, E. M., \& Gillespie, J. (2009). How study abroad shapes global careers: Evidence from the United States. Journal of Studies of International Education, 13(3), 382-397.

O'Carroll, I., \& Collins, E. (1996). Lesbian and gay visions of Ireland: Towards the twenty-first century. New York, NY: Cassell.

Opper, S., Teichler, U., \& Carlson, J. (1990). Impacts of study abroad programmes on students and graduates. London, UK: Jessica Kingsley Publishers.

Otero, M. S. (2008). The socio-economic background of Erasmus students: A trend towards wider inclusion? International Review of Education, 54(2), 135-154.

Parker, R. G. (1999). Beneath the equator: Cultures of desire, male homosexuality, and emerging gay communities in Brazil. New York, NY: Routledge.

Rhodes, G., Biscarra, A., Loberg, L., \& Roller, K. (2012). Study abroad as a collaborative endeavor. About Campus, 16(6), 2-10. doi: 10.1002/abc.20081

Salisbury, M. H., Paulsen, M. B., \& Pascarella, E. T. (2011). Why do all study abroad students look alike? Applying an integrated student choice model to explore differences in the factors that influence white and minority students' intent to study abroad. Research in Higher Education, 52(2), 123-150. doi: 10.1007/s11162-010-9191-2

Scheib, M., \& Mitchell, M. (2008). Awaiting a world experience no longer: It's time for all students with disabilities to go overseas. In T. Berberi, E. C. Hamilton, \& I. M. Sutherland (Eds.). Worlds apart?: Disability and foreign language learning. New Haven, CT: Yale University Press.

Schmidt, P. (2009). Men and women differ in how they decide to study abroad, study finds. The Chronicle of Higher Education, Retrieved from http://chronicle.com/article/MenWomen-Differ-in-How/49085/

Seabrook, J., \& Gopalan, A. (1999). Love in a different climate: Men who have sex with men in India. New York, NY: Verso Books.

Shames, W., \& Alden, P. (2005). The impact of short-term study abroad on the identity development of college students with learning disabilities and/or ad/hd. Frontiers: The Interdisciplinary Journal of Study Abroad, 11, 1-31.

Shea, P. (2001). Being gay, lesbian, bisexual, or transgender abroad. Paper presented at the NAFSA 2001 Conference. Retrieved from http://overseas.iu.edu/lesbigay/nafsa_2001_presen.htm

Soneson, H. M., \& Cordano, R. J. (2009). Universal design and study abroad: (Re-) designing programs for effectiveness and access. Frontiers: The Interdisciplinary Journal of Study Abroad, 18, 269-288.

Soneson, H. M., \& Fisher, S. (2011). Education abroad for students with disabilities: Expanding access. New 
Directions for Student Services, (134), 59-72.

Soria, K. M., \& Barratt, W. (2012, June). Examining class in the classroom: Utilizing social class data in institutional and academic research. Association for Institutional Research Forum, New Orleans, LA.

Soria, K. M., \& Troisi, J. N. (2013). Internationalization at home alternatives to study abroad: Implications for students' development of global, international, and intercultural competencies. Journal of Studies in International Education (currently in "online first" format).

Stebleton, M. J., Soria, K. M., \& Cherney, B. (2013). The high impact of education abroad: College students' engagement in international experiences and the development of intercultural competencies. Frontiers: The Interdisciplinary Journal of Study Abroad, 22, 1-24.

Stevens, R.A. (2004). Understanding gay identity development within the college environment. Journal of College Student Development, 45(2), 185-206. doi: 10.1353/csd.2004.0028

Suicide Prevention Resource Center. (2008). Suicide risk and prevention for lesbian, gay, bisexual, and transgender youth. Retrieved from http://www.sprc.org/sites/sprc.org/files/library/SPRC_LGBT_Youth.pdf

Summerhawk, B., McMahill, C., \& McDonald, D. (Eds.). (1998). Queer Japan: Personal stories of Japanese lesbians, gays, transsexuals and bisexuals. New York, NY: New Victoria Publishing.

Talburt, S., \& Stewart, M. A. (1999). What's the subject of study abroad? Race, gender, and "living culture." The Modern Language Journal, 83(2), 163-175.

Thatchell, P. (1992). Europe in the pink: Lesbian and gay equality in New Europe. London, UK: Gay Men's Press.

Troiden, R. R. (1989). The formation of homosexual identities. Journal of Homosexuality, 17 (1-2), 43-74.

Twill, S. E., \& Guzzo, G. R. (2012). Lessons learned from a disabilities accessible study abroad trip. Journal of Postsecondary Education and Disability, 25(1), 81-86.

Twombly, S. B. (1995). Piropos and friendships: Gender and culture clash in study abroad. Frontiers: The Interdisciplinary Journal of Study Abroad, (1), 1-16.

Twombly, S. B., Salisbury, M. H., Tumanut, S. D., \& Klute, P. (2012). Study abroad in a new global century: Renewing the promise, refining the purpose. ASHE Higher Education Report, 38(4), 1-152.

U.S. Department of State. (2013). LGBT travel information. Retrieved from http://travel.state.gov/travel/cis_pa_tw/lgbt/lgbt_5887.html 